\title{
Dampak Drama Korea (Korean Wave) terhadap Pendidikan Remaja
}

\author{
Rahayu Putri Prasanti ${ }^{1]}$, Ade Irma Nurmala Dewi ${ }^{2]}$ \\ Universitas Negeri Surabaya \\ E-mail: ${ }^{11}$ rahayu.18016@mhs.unesa.ac.id \\ ${ }^{2]}$ ade.18040@mhs.unesa.ac.id
}

\begin{abstract}
Abstrak
Budaya korea atau yang biasa disebut sebagai Hallyu telah menghasilkan banyak produk seperti film, music, makanan, drama seri, fashion, serta gaya hidup. Produk-produk Hallyu tersebut telah tersebar ke seluruh penjuru dunia seiring berkembangnya ilmu pengetahuan dan teknologi. Drama korea atau yang lebih dikenal dengan sebutan Drakor menjadi salah satu produk hallyu yang paling digemari oleh remaja Indonesia saat ini lebih lagi dengan adanya pandemic saat ini penonton drakor sangat meningkat tajam dari kalangan remaja . Penelitian ini bertujuan untuk mengetahui bagaimana dampak drama korea dalam pendidikan khusunya remaja. Penelitian ini dilaksanakan pada bulan April 2020 dan merupakan penelelitian kualitatif. Populasi dan sampel dalam penelitian ini berjumlah 12 mahasiswa. Pengumpulan data dilakukan melalui wawancara online melalui pengisian kuisioner. Penelitian ini menggunakan pendekatan kualitatif dengan rancangan etnografi. Data penelitian dianalisis dengan menggunakan aplikasi Nvivo 12. Hasil penelitian menunjukkan bahwa drama korea memiliki dampak positif dan dampak negatif terhadap pendidikan remaja. Dampak positif dari kegemaran mereka menonton drama korea adalah memberi motivasi belajar, mendapat pengetahuan baru, mengenal budaya pendidikan Korea Selatan, adanya semangat untuk mengikuti program beasiswa ke Korea Selatan, belajar bahasa baru. Sedangkan dampak negatifnya adalah malas belajar, menunda pekerjaan, berkurangnya waktu belajar dan istirahat, tidak fokus dalam belajar, kesehatan berkurang dalam menunjang aktivitas sebagai peserta didik. Berdasarkan data ini maka dapat disimpulkan bahwa terdapat dampak yang ditimbulkan dari drama korea ini terhadap pendidikan remaja.
\end{abstract}

KataKunci : Drama Korea, Pendidikan Remaja, Hallyu

\section{The Impact of Korean Drama (Korean Wave) on Youth Education}

\begin{abstract}
Korean culture or commonly referred to as Hallyu has produced many products such as films, music, food, drama series, fashion, and lifestyle. The Hallyu products have spread throughout the world as science and technology develop. Korean drama or better known as Drakor has become one of the most popular hallyu products by Indonesian teenagers, which is now even more so with the current pandemic that has dramatically increased the
\end{abstract}

Lectura: Jurnal Pendidikan, Vol.11 No. 2, Agustus 2020 
audience of teenagers. This research aims to find out how the impact of Korean drama in education. This research was conducted in April 2020. This research is a qualitative research. The population and sample in this study were 12 students. Data collection was carried out through online interviews through questionnaires. This research uses an ethnographic approach with ethnographic design. Research data were analyzed using Nvivo 12. The results showed that Korean drama has positive and negative impacts on teen education. The positive impact of their penchant for watching Korean dramas is to motivate learning, gain new knowledge, get to know the culture of South Korean education, have an enthusiasm to attend a scholarship program to South Korea, learn a new language. While the negative effects are lazy learning, delaying work, reduced learning time and rest, are not focused on learning, health is reduced in supporting activities as students. Based on this data it can be concluded that there is an impact caused by this Korean drama on teeneducation.

Keywords: Korean Drama, Youth Education, Hallyu

\section{PENDAHULUAN}

Korea Selatan merupakan negara yang berada di Asia Timur yang berada di selatan Semenanjung Korea berada diantara negara Republik Rakyat Tiongkok dan Jepang. Di bagian Utara Semenanjung Korea adalah negara Korea Utara. Korea Selatan memiliki berbagai macam corak kebudayaan yang beragam seperti makanan, busana, music, anime, video game serta drama seri. Melalui perkembangan komunikasi dan media massa dewasa ini kebudayaan Korea Selatan dapat dinikmati di manapun dan menciptakan gelombang korea atau biasa disebut Korean wave. Penyebaran kebudayaan Korea Selatan secara global ini disebut Hallyu, Cheonosa (dalam Khairunnisa, 2019: 2).

Dirujuk dari Kedutaan Besar Korea Selatan untuk Republik Indonesia, istilah Hallyu merupakan istilah yang digunakan untuk menjelaskan penyebaran kebudayaan korea selatan secara global ke berbagai negara di seluruh dunia pada sekitar awal tahun 1990. Hallyu merupakan kata yang didapat dari kata han (한) yang diambil dari kata hanguk (한국) yang memiliki arti Koreadan ryu (류) yang berarti aliran/gelombang, kemudian digabung menjadi kata 한류"hanryu” dibaca "hallyu" yang memiliki arti gelombang korea.Hallyu sendiri memiliki beberapa konten-konten kebudayaan yang diantaranya adalah $K$ Pop atau musik pop korea, drama TV atau yang lebih dikenal dengan sebutan drakor, film, kuliner, kecantikan, sastra, bahasa, budaya lokal hingga fashion.

Hallyu muncul pada pertengahan 1990an setelah pemerintah Korea Selatan mengadakan hubungan diplomatic dengan Tiongkok, yang membuat drama dan music korea mulai digemari di negara tersebut. Salah satu drama korea yang berhasil adalah What is Love yang ditayangkan oleh CCTV tahun 1997 yang mendapatkan penonton lebih dari 150 juta pemirsa Tiongkok. Untuk music pop mulai dikenal setelah salah satu program radio di Tiongkok bernama Seoul Music Room di Beijing pada tahun 1997. Adanya konser boyygrup besutan SM Entertaiment bernama H.O.T yang diselenggarakan di Beijing pada tahun

Lectura: Jurnal Pendidikan, Vol.11 No. 2, Agustus 2020 
2000.Mulai saat itu istilah Hallyu mulai dikenal masyarakat luas.

Drama korea merupakan salah satu hasil dari kebudayaan Hallyu yang paling digemari oleh banyak masyarakat di dunia. Drama merupakan karya sastra yang dirancang untuk dipentaskan di panggung oleh para actor dan aktris (Rohmanto, 2014:11). Sedangkan drama korea adalah budaya kesenian yang mengacu kepada drama televisi di Korea dalam sebuah format miniseri dan menggunakan bahasa korea dimana dalam drama korea mengangkat kisah-kisah kehidupan manusia yang disajikan menggunakan bahasa korea sebagai bahasa pengantarnya.

Seiring dengan adanya globalisasi yang menyebabkan adanya kemajuan di bidang IPTEK, saat ini drama korea mulai dipertontonkan dalam bentuk perfilman dan bisa dinikmati dalam layar televisi. Adanya ekspor drama dan film korea ke luar negeri menjadikan drama korea dikenal luas di dunia. Banyak dari drama ini yang menjadi populer di seluruh Asia dan telah memberi kontribusi pada fenomena umum dari gelombang korea, dan juga demam drama di beberapa negara.

Perkembangan industri di Korea membuka peluang perkembangan potensi budayanya melalui musik, fashion dan perfilman untuk diperkenalkan kepada negara lain. Indonesia pun setiap tahunnya sering mengadakan kegiatan pekan budaya Korea Selatan di berbagai daerah. Kerja samaantara Korea dengan Indonesia dan sejumlah Perguruan Tinggi dalam negeri serta masyarakat membuat usaha untuk menyebarluaskan budaya mereka. Kesuksesan drama korea tidak terlepas dari ide kreatifitas dan imajinasi yang dikembang-kan oleh pekerja seni. Drama Korea juga mengangkat kebudayaan, kehidupan dan masalah seharihari serta kisah yang tidak bertele-tele membuat masyarakat hampir di seluruh Asia bahkan dunia menyukainya baik dari kalangan remaja maupun orang dewasa terutama kalangan kaum hawa. Drama korea juga tidak hanya menyajikan satu genre saja, tetapi berbagai macam genre yang menjadikannya menarik untuk ditonton.

Adapun pengertian genre dapat dipahami sebagai tipe atau kategori pengelompokan karya sastra yang biasanya berdasarkan bentuk atau isi (Nurgyantoro, 2004: 110). Berbagai genre yang disajikan seperti action, misteri, horror, romansa, sekolah, politik, komedi, slice of life, sains fiction, medis, keluarga. Beberapa drama korea yang berhasil menyebarkan budaya hallyu di Indonesia antara lain Boys Before Flowers (2009), Winter Sonata (2002), Full House (2004), The Heirs (2013), Descendents of the Sun (2016), Goblin (2017), The World of the Married (2020).

Saat ini banyak stasiun televisi di Indonesia yang menayangkan konten dari luar negeri tak terkecuali drama dan film Korea. Drama dan film korea yang diterima baik oleh masyarakat Indonesia membuat banyak stasiun televisi Indonesia berlomba-lomba menayangkan drama korea untuk memikat hati penonton Indonesia khususnya remaja. Kehadiran drama dan film korea di berbagai stasiun televisi ini diterima dengan baik oleh masyarakat karena tidak harus mengunduh drama korea dari platform illegal namun juga memiliki kemudahan dengan menggunakan pengisi suara berbahasa Indonesia. Apalagi drama korea disajikan dengan konflik yang beragam dam menarik membuat orang-orang utamanya remaja merasa ikut terhanyut dalam cerita yang ada.

Remaja adalah masa dimana terjadi transisi atau masa peralihan dari kehidupan anak-anak menuju ke 
kehidupan dewasa. Tidak hanya dalam bentuk fisik saja, remaja juga akan mengalami perubahan dalam segi psikologisnya. Dalam segi fisik sudah bisa diatakan "dewasa" namun apabila diperlakukan seperti layaknya orang dewasa remaja gagal menunjukkan kedewasaannya (Putro, 2017: 25). Remaja cenderung memiliki keinginan untuk mencoba hal-hal baru dan tidak mau dikekang. Oleh karena itu saat remaja dihadapkan dengan berbagai macam tugas dari sekolah mereka akanmencari pelarian untuk menenangkan diri mereka salah satunya drama korea.

Drama korea saat ini menjadi tren di kalangan remaja. Remaja menjadikan menonton drama korea sebagai pengisi waktu luang. Banyak nya kegiatan yang dilakukan remaja, seperti jadwal kuliah yang padat serta tugas kuliah yang menumpuk terkadang membuat suasana hati mereka menjadi suntuk dan jenuh, sehingga untuk mengantisipasi rasa jenuhnya, remaja mencoba mengisi waktu luang untuk menonton berbagai film.

Motif remaja dalam menonton drama hanya untuk mengisi waktu luang dan sebagai hiburan untuk menghilangkan kejenuhan, namun ada juga yang menjadikan Drama Korea sebagai kebutuhan sehari-hari. tidak sedikit remaja berlama-lama menonton drama korea hingga menghabiskan waktu dengan sia-sia, melupakan lingkungan baik, teman, keluarga, dan masyarakat serta melupakan kehidupan nyata, sehingga menyebabkan kurangnya hidup bersosial. Dan tidak sedikit yang mengesampingkan pendidikan demi melihat drama korea.

Pada dasarnya belajar merupakan hak seluruh umat manusia.Ainurrahman (dalam Dasopang, 2017: 335) menjelaskan bahwa belajar merupakan perubahan perilaku sebagai hasil interaksi dengan lingkungannya. Proses interaksi individu dengan lingkungannya dalam hal ini adalah obyek-obyek yang memungkinkan individu mendapatkan pengetahuan dan pengalaman dari proses tersebut. Belajar tidak diharuskan melalui media formal utamanya sekolah. Berbagai media pembelajaran yang saat ini berkembang menjadi salah satu kemudahan dalam belajar, tidak terkecuali drama korea. Drama korea bisa menjadi alternatif media belajar sekaligus hiburan bagi remaja. Melalui drama korea remaja dapat belajar bahasa baru, kebudayan setempat, serta informasi yang disajikan dalam drama tersebut. Genre pendidikan yang menjadi favorit remaja dapat menjadi pengetahuan baru bagi remaja mengenai sistem pendidikan di Korea Selatan serta menjadikannya sebagai motivasi dalam belajar dan menempuh pendidikan yang lebih tinggi.

Lalu bagaimana dampak bagi mahasiswa yang sangat menyukai drama korea berlebihan yang berpengaruh kepada aktivitas kehidupan sehari-hari sebagai mahasiswa. Lalu bagaimana dengan tugasnya sebagai seorang mahasiswa saat memilih untuk menunda tugas dan mengabaikan kegiatan nya hanya untuk menonton kelanjutan film dan drama korea tersebut.

Hal ini menjadi kekhawatiran peneliti karena banyaknya efek negatif dari drama korea nantinya akan mempengaruhi pendidikan mereka utamanya adalah prestasi. Mereka para remaja menghabiskan waktu ber jamjam hanya untuk melihat drama korea, bahkan tidak jarang mereka merelakan waktu tidur mereka hanya untuk menyelesaikan episode yang dirasa sangat tanggung jika tidak dilanjutkan. Cara berpikir mereka pun juga dapat terganggu apabila jalan cerita drama korea yang mereka lihat cenderung pada adegan yang seharusnya tidak mereka lihat di usia mereka, seperti 
pembunuhan, memaki, pergaulan bebas dan masih banyak lagi.

Hal-hal yang telah dikemukakan di atas menjadi latar belakang penelitian yang berjudul "Dampak Drama Korea (Korean Wave) terhadap Pendidikan Remaja".

\section{METODE}

Dalam penelitian terdapat dua jenis metode yang dapat digunakan oleh peneliti yaitu metode penelitian dengan pendekatan kuantitatif dan metode penelitian dengan pendekatan kualitatif atau bahkan dengan gabungan dari kedua pendekatan. Dalam penelitian kali ini peneliti menggunakan metode penelitian pendekatan kualitatif dengan rancangan etnografi.

Penelitian ini menggunakan metode penelitian pendekatan kualitatif dengan menggunakan rancangan etnografi. Metode penelitian pendekatan kualitatif adalah metode penelitian yang menghasilkan penemuanpenemuan yang tidak bisa dicapai melalui proses statistic atau bisa disebut kuantitatif (Nugrahani, 2014:4). Desain penelitian kualitatif berkonsentrasi pada ujian formal dari hipotesa dan ahli teori desain eksperimen utama untuk mendapatkan data, gagasan serta hasil yang murni dan terdapat penegasan di dalamnya (Manab, 2015:4). Dalam penelitian kualitatif ini peneliti diajak untuk memamahi kata demi kata, menyusun gambaran mengenai penelitian dan menyimpulkannya menjadi sebuah fakta yang terdapat di lapangan.

Adapun tujuan dari dilakukannya penelitian kualitatif menurut (Nugrahani, 2014:4) adalah untuk memahami suatu topic permasalahan yang diarahkan pada pendeskripsian secara rinci dan mendalam mengenai kondisi dalam suatu topik/konteks alami (natural setting), tentang apa yang sebenarnya terjadi di lapangan saat penelitian. Tidak jauh berbeda dengan pendapat di atas (Manab, 2015: 5) berpendapat bahwa tujuan diadakannya penelitian kualitatif adalah mendapat pemahaman mendalam tentang proses interaksi, nilai-nilai, pengalaman individu dan kelompok yang terjadi secara alami.

Ada berbagai rancangan yang digunakan dalam metode penelitian pendekatan kualitatif, salah satunya adalah rancangan penelitian etnografi. Rancangan penelitian Etnografi adalah model penelitian yang lebih banyak terkait dengan antropologi yang mempelajari dan mengeskplor peristiwa cultural dalam suatu masyarakat (Windiani \& R, Farida Nurul, 2016: 88). Rancangan etnografi berfokus pada individu sebagai subjek penelitian untuk mengetahui gambaran umum suatu subjek penelitian. Maka dari itu penelitian ini menggunakan metode penelitian pendekatan kualitatif dengan rancangan penelitian etnografi karena penelitian ini meneliti mengenai kebudayaan Korea Selatan yang mendunia atau yang biasa disebut Hallyu yang mencakup bahasa, pola perilaku, sastra, dan kebiasaan yang tertuang dalam serial drama serta dampaknya bagi pola pikir remaja khususnya dalam pendidikan. Karena dalam praktiknya penelitian ini menggunakan hal yang dikatakan oleh orang dalam upaya mendeskripsikan kebudayaan orang tersebut dalam bentuk drama seri. Selain itu peneliti juga ingin mengetahui seberapa dalam budaya Korea Selatan khususnya dalam bidang pendidikan mempengaruhi pendidikan remaja itu sendiri. Seperti yang kita ketahui bahwa dalam drama korea terdapat banyak sekali budaya yang ditampilkan seperti gaya hidup dan bahasa.

Populasi sekaligus sampel dari penelitian ini adalah beberapa remaja yang masih menjalankan pendidikan di 
Perguruan Tinggi Negeri. Data kualitatif ini diambil dari 12 orang yang berstatus sebagai remaja akhir (usia 17-20 tahun) mahasiswamahasiswi Universitas Negeri Surabaya dengan berbagai bidang ilmu sebagai informan untuk wawancara online melalui pengisian kuisioner. Dipilih remaja akhir karena remaja akhir sudah dianggap hampir dewasa dan berada pada perbatasan untuk masuk ke dalam kehidupan orang dewasa.

Data ini bertujuan untuk mencari informasi terkait dengan dampak drama korea terhadap pendidikan remaja. Seluruh data wawancara online dianalisis secara tematik menggunakanalat analisis Nvivo. Selain itu peneliti juga menggunakan kajian pustaka seperti buku, jurnal, majalah atau artikel, internet (web) sebagai penunjang dalam menggali informasi terkait masalah yang sedang dikaji.

\section{HASIL DAN PEMBAHASAN}

\subsection{Hasil Penelitian}

Hasil penelitian dilaporkan secara keseluruhan melalui hasil analisis tematik data kualitatif yang diambil melalui wawancara online dengan seluruh informan .Gambaran dan pembahasan hasil analisis kualitatif dapat dilihat pada Gambar 1.

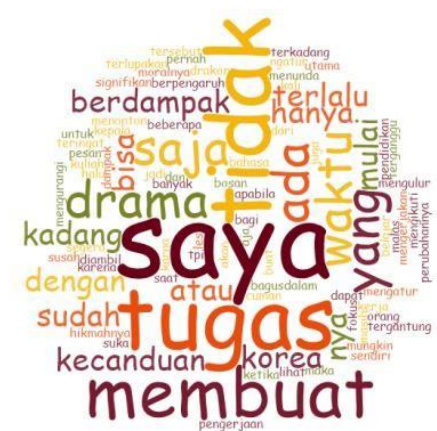

Gambar 1. Hasil output Nvivo

Dalam gambar di atas dapat dilihat beberapa kata yang dihasilkan dari wawancara online 12 informan.Ada beberapa kata yang mendominasi hasil analisis dari aplikasi Nvivo 12 yang digunakan oleh peneliti.Beberapa kata yang mendominasi seperti saya, tugas, membuat, tidak oleh peneliti dianalisis lebih dalam lagi dan dicocokkan dengan jawaban dari wawancara online dari informasn untuk mendapatkan hasil yang diinginkan.

Adapun petikan wawancara online dari beberapa informan akan digambarkan pada tabel 1, 2, 3, dan 4 .

Tabel 1. Petikan Wawancara tentang Dampak Drama Korea terhadap Pendidikan Remaja

\begin{tabular}{ccl}
\hline No & Informan & \multicolumn{1}{c}{$\begin{array}{c}\text { Petikan } \\
\text { Wawancara }\end{array}$} \\
\hline 1 & Informan 1 & Tidak ada dampaknya, cuman suka halu aja. \\
2 & Informan 2 & $\begin{array}{l}\text { Tidak berdampak hanya saja ketika ada drakor yang } \\
\text { bagus akan teringat di kepala. }\end{array}$ \\
3 & Informan 3 & $\begin{array}{l}\text { Saya sendiri sudah mulai mengurangi drama yang saya } \\
\text { lihat, apabila tugas banyak. Dengan ada tugas tersebut } \\
\text { membuat saya mulai bosan dengan drama Korea. } \\
\text { Kadang juga terganggu, tapi masih fokus ke pendidikan } \\
\text { yang utama. }\end{array}$
\end{tabular}


6 Informan 8 Tidak signifikan perubahannya atau mungkin bisa diambil hikmahnyaatau pesan moralnya saja.

7 Informan 9 Kadang membuat saya mengulur waktu untuk segera mengerjakan tugas.

8 Informan 12 Tidak terlalu berpengaruh. Hanya saja pernah beberapa kali mengikutiles bahasa korea.

Dari Tabel 1. Di atas, petikan wawancara dari beberapa informan mengenai dampak yang ditimbulkan oleh drama korea terhadap pendidikan remaja. Dari tabel tersebut dapat kita dapat ketahui bahwa terdapat dampak yang ditimbulkan dari drama korea terhadap pendidikan. Beberapa informan melihat dan mengatakan bahwa walau melihat drama korea untuk mengisi waktu luang, pendidikan tetap menjadi yang terpenting bagi mereka. Bisa diartikan bahwa drama korea bukan sebagai penghalang dalam melakukan tugas sebagai seorang pelajar.
Sehingga dapat ditarik kesimpulan bahwa beberapa informan tidak mempengaruhi pendidikan mereka saat menonton drama korea. Dan selanjutnya beberapa informan lainnya mengatakan bahwa melihat drama korea berpengaruh pada pengerjaan tugas misalnya sering menunda pengerjaan tugas rumah dan lebih memilih menonton drama korea. Hal tersebut tentu saja merupakan efek negative yang ditimbulkan oleh drama korea dan ada juga yang mengambil efek positifnya yaitu bisa belajar bahasa asing selain bahasa Inggris yaitu bahasa korea.

Tabel 2. Petikan Wawancara tentang Pengaruh Drama Korea terhadap Pandangan Informan terhadap Pendidikan

\begin{tabular}{lll}
\hline No. & Informan & \multicolumn{2}{c}{ Petikan } \\
\hline 1 & Informan 2 & Ketika kita punya keinginan yang besar maka kita harus \\
& tetap berusaha konsisten untuk meraihnya. \\
2 & Informan 3 & $\begin{array}{l}\text { Ada materi dan metode pembelajaran yang } \\
\text { tidakditerapkan di Indonesia sehingga dapat menambah }\end{array}$ \\
& wawasansaya. Dan cara pandang pendidikan di drama \\
& banyak orang tua yang menekan siswa harus \\
& menentukan cita-cita sejak dini agar saat diakhir \\
& sekolah mudah untuk diterima dalam universitas \\
& favorit.
\end{tabular}

3 Informan 4 Di Korea terdapat ujian masuk perguruan tinggi yang dianggap penting oleh orang korea. Maka menjadi motivasi juga saat kuliah.

$4 \quad$ Informan 8 Drama yang bertema kesehatan akan membantu menambah pengetahuan bagi yang mengambil pendidikan tersebut, begitupun bertema hukum.

5 Informan 9 Bahwa menempuh pendidikan itu tidak mudah, banyak Perjuangan yang harus dilalui. 
6 Informan Ternyata pendidikan di setiap negara itu berbeda-beda 11 contoh saja di Korea Selatan, waktu yang digunakan untuk sekolah dan belajar lebih banyak daripada bermain dan waktu istirahat yang diberikan juga sedikit.

7 Informan Sangat penting karena pendidikan merupakan hal 12 yang penting untuk bisa berkomunikasi dan menginterprestasikan sesuatu.

Dari Tabel 2. diatas, dapat kita lihat beberapa petikan wawancara dengan informan mengenai pandangannya terhadap pendidikan. Dari petikan di atas, pandangan informan terhadap pendidikan cukuplah baik. Di dalam drama korea khususnya pada genre pendidikan menampilkan bahwa pendidikan disana sangatlah baik dan juga sangat lebih maju dibandingkan di Indonesia . Oleh karena itu, drama korea menambah wawasan kehidupan termasuk pendidi-kan. Bukan hanya drama dengan genre pendidikan, genre lainnya pun juga bisa member pengetahuan umum kepada remaja yang menontonnya." Ternyata pendidikan di setiap negara itu berbeda beda contoh saja di Korea Selatan waktu yang digunakan untuk sekolah dan belajar lebih banyak daripada bermain dan waktu istirahat yang diberikan juga sedikit"(Felly).

Tabel 3. Petikan Wawancara tentang Efek Positif yang Ditimbulkan Karena Menonton Drama Korea bagi Pendidikan

\begin{tabular}{|c|c|c|}
\hline & Informan & $\begin{array}{c}\text { Petikan } \\
\text { Wawancara }\end{array}$ \\
\hline 1 & Informan 1 & Ada pengetahuan baru \\
\hline 2 & Informan 3 & $\begin{array}{l}\text { Dalam drama Korea banyak yang dapat kita ambil dari } \\
\text { cara mencari teman dan pekerjaan ( dalam drama } \\
\text { Cheese in the Trap), solusi belajar (dalam drama God of } \\
\text { Study), dan masih banyak drama Korea yang } \\
\text { mengandung efek positif terlebih dalam drama Korea } \\
\text { yang bertema sekolah. }\end{array}$ \\
\hline 3 & Informan 7 & $\begin{array}{l}\text { Membuat seseorang jadi lebih semangat dalam } \\
\text { menjalani aktivitas. }\end{array}$ \\
\hline 4 & Informan 8 & $\begin{array}{l}\text { Jika sedang menempuh pendidikan kedokteran } \\
\text { atau kesehatan, drakor yang bertema kesehatan dapat } \\
\text { berpengaruh mengenai informasi baru yang sebelumnya } \\
\text { tidak tahu, begitu pun juga yang bertema hukum. } \\
\text { Berguna bagi jurusan atau yang menempuh ilmu } \\
\text { hukum. }\end{array}$ \\
\hline 5 & Informan 9 & Lebih banyak mengenal jenis-jenis profesi \\
\hline 6 & $\begin{array}{l}\text { Informan } \\
11\end{array}$ & $\begin{array}{l}\text { Mempertahankan apa yang kita inginkan dan berusaha } \\
\text { untuk meraihnya. }\end{array}$ \\
\hline
\end{tabular}


7 Informan Banyak pengetahuan. Karena drakor tidak melulu 12 mengenai percintaan tapi ada juga yang berhubungan dengan rumah sakit dan pemerintahan.

$\begin{array}{ll}\text { Dari tabel 3.diatas merupakan tabel } & \text { yang mengandung efek positif terlebih } \\ \text { petikan wawancara dari beberapa } & \text { dalam drama Korea yang khususnya } \\ \text { informan yang berpendapat tentang efek } & \text { bertema tentang pendidikan. Jadi } \\ \text { positif dari menonton drama korea. Dari } & \text { kesimpulan dari tabel 3 di atas, drama } \\ \text { tabel diatas dapat kita ketahui ternyata } & \text { korea bukan hanya film sinetron biasa } \\ \text { banyak efek positif dari menonton drama } & \text { yang bertema percintaan atau yang } \\ \text { korea misalnya menambah pengetahuan } & \text { lainnya Tetapi drama korea juga } \\ \text { baru, tetap semangat dalam menjalani } & \text { mengandung unsur positif yang baik } \\ \text { kehidupan, dan dari cara mencari teman } & \text { untuk diterapkan di kehidupan sehari-hari. } \\ \text { dan pekerjaan (dalam drama Cheese in the } & \text { Sehingga tidak salah bahwa penggemar } \\ \text { Trap), solusi belajar (dalam drama God of } & \text { atau penonton drama korea di Asia ini } \\ \text { Study), dan masih banyak drama Korea } & \text { cukuplah } \\ & \end{array}$

Tabel 4. Petikan Wawancara tentang Efek Negative yang Ditimbulkan Karena Menonton Drama Korea bagi Pendidikan

\begin{tabular}{|c|c|c|}
\hline No. & Informan & PetikanWawanca \\
\hline 1 & Informan 2 & Tidak mengenal waktu, jam istirahat menjadi kacau. \\
\hline 2 & Informan 3 & $\begin{array}{l}\text { Saya sendiri bisa menyia-nyiakan waktu untuk belajar, } \\
\text { sekali lihat Drakor bisa sampai begadang padahal masuk } \\
\text { pagi saat sekolah, dan mungkin dalam Drakor ada } \\
\text { adegan yang untuk usia } 20+\text { yang bisa mempengaruhi } \\
\text { otak pesertadidik. }\end{array}$ \\
\hline 3 & Informan 4 & Menjadi sedikit malas. \\
\hline 4 & Informan 5 & Kecanduan. \\
\hline 5 & Informan 6 & Orang menjadi banyak drama. \\
\hline 6 & Informan 7 & $\begin{array}{l}\text { Kurang fokus dan pendidikan jadi terganggu karena } \\
\text { kecanduan. }\end{array}$ \\
\hline 7 & Informan 8 & Dari segi kekerasannya (kalau ada). \\
\hline 8 & Informan 9 & Lupa \\
\hline 9 & Informan 10 & $\begin{array}{l}\text { Banyak, bisa terpengaruh sama gaya hidup di sana, suka } \\
\text { berhalu. Mungkin juga kepikiran drakor itu sehingga } \\
\text { tidak fokus belajar. }\end{array}$ \\
\hline 10 & Informan 11 & Malas belajar yang utama dan tidak mengenal waktu. \\
\hline 11 & Informan 12 & Kecanduan. \\
\hline
\end{tabular}


Tabel 4. merupakan tabel petikan wawancara dari beberapa informan yang berpendapat tentang efek negatif dari menonton drama korea bagi pendidikan. Dari tabel di atas kita lihat bahwa drama korea bisa berdampak atau berefek negative bagi pendidikan remaja karena drama korea menimbulkan atau menyebabkan sifat kecanduan bagi para penonton. Sehingga terkadang membuat para penonton drama korea menjadi lupa waktu dan pendidikan tetapi semua itu tetap tergantung setiap individu dalam menelaah drama korea dan mengatur jam menonton.

\subsection{Pembahasan}

Dalam penelitian ini, dipilih informan dengan umur 18-20 tahun yang sedang menempuh pendidikan strata 1 di Universitas Negeri Surabaya. Seluruh informan mengetahui dan melihat drama korea sebagai hiburansaat waktu luang. Hampir semua informan mengetahui budaya Hallyu ini dan menjadikannya sebagai salah satu kebudayaan yang mereka gemari untuk dilihat lebih lahi dengan adanya pandemic saat ini. Semua informan lebih memiliki banyak waktu luang untuk menonton drama korea atau lebih dikenal dengan sebutan drakor.

Berbagai macam pendapat yang telah disampaikan olehke-12 informan secara berbeda-beda dan masing-masing informan-pun memiliki keunikannya tersendiri dalam menanggapi dampak drama korea terhadap pendidikan mereka. Ada beberapa pendapat yang telah disampaikan oleh informan dan dari pendapat itu peneliti menyimpulkan adanya dampak positif dan negatif atas kegemaran menonton drama korea. Adapun dampak negatif dari drama korea yang telah dipaparkan oleh informan yang pertama adalah munculnya gejala halu. Banyak dari informan mengatakan bahwa menonton drama korea membuat mereka menjadi halu. Halu adalah bahasa gaul yang sering digunakan oleh remaja saat ini untuk menyebutkan katahalusinasi atau sesuatu yang hanya dapat mereka rasakan namun sebenarnya tidak ada. Halu sering dikaitkan dengan para pemain drama korea yang memiliki wajah rupawan dan sesuai dengan kriteria idaman para penonton dan seakan merasakan bahwa mereka menjadi atau berpartisipasi dalam drama, bahkan tidak sedikit dari mereka yang ber-halu menjadi pasangan hidup mereka. Dalam sei psikologis tentu hal ini akan mengganggu kemampuan berpikir mereka. Walaupun halu juga bisa menandakan adanya kemampuan kreatifitas otak yang tinggi, namun jika tidak digunakan dengan hal positif maka akan sia-sia dan mengganggu kegiatan sehari-hari termasuk dalam hal pendidikan.

Elkind \& Bowen (dalam Herlina, 2013) mengatakan bahwa remaja cenderung memiliki pendengaran imajiner. Dimana mereka akan menganggap diri mereka selalu di atas panggung dan menjadi pusat perhatian orang lain. Selain itu dongeng pribadi (personal fable) yang menunjukkan bahwa remaja merasa yakin bahwa mereka diperhatikan dan dipikirkan oleh orang lain. Maka saat remaja melihat sosok tokoh idola yang mereka anggap mirip dengan kriteria pasangannya atau sosok idola yang menjadi panutannya, mereka secara sadar dan tidak sadar akan berhalusinasi seakan-akan mereka menjadi orang terdekat dari sosok yang mereka idolakan tersebut. Karena itu jika apa yang mereka inginkan namun tidak dapat tercapai mereka akan marah dan menganggap orang lain tidak mengerti apa yang mereka rasakan dan melakukan tindakan yang dapat membahayakan bagi mereka dan orang lain. Hal itu juga menjadi salah satu alasan bagi banyak remaja yang suka meributkan idolanya di media sosial dan cenderung melakukan tindakan merugikana dirinya dengan mengunggah komentar negatif tentang 
orang lain. Dengan seperti itu waktu belajar mereka akan terbuang sia-sia karena terlalu sibuk mengurusi hal-hal yang seharusnya tidak perlu mereka pikirkan dalam-dalam.

Yang kedua adalah adanya gangguan tidur. Sebagaimana kita tahu tidur cukup menjadi salah satu penentu mutu belajar dari seorang pelajar. Dikutip dari Kompas.com remaja umumnya memiliki kebutuhan tidur kurang lebih 8-9 jam per harinya. Apabila kurang dari waktu tersebut maka remaja akan mudah terkena depresi dan tidak fokus di sekolah. Dilihat dari wawancara online yang dilakukan beberapa informan mengatakan bahwa jadwal tidur mereka terganggu karena harus menyelesaikan drama dalam sekali waktu untuk mengurangi rasa penasaran mereka.dengan jadawal tidur yang tidak menentu dan kurang membuat kinerja mereka di sekolah menjadi menurun juga. Tidak fokus dalam pembelajaran dan mengantuk di kelas merupakan salah satu dampak kurang tidur karena menonton drama korea.

Dampak negatif yang didapat dari melihat drama koreayang ketiga adalah kecanduan. Banyak dari informan yang mengatakan bahwa cerita yang disuguhkan dalam drama korea sangat menarik dan berbeda dengan sinema elektronik atau sinetron dalam negeri. Dalam drama korea terdapat banyak genre yang ditampilkan seperti melo drama, medis, hukum, slice of life, misteri, horror, fantasi hingga sejarah. Bagi pecinta drama, keberagaman genre itulah yang membuat drama asal Korea Selatan ini menjadi keunikannya tersendiri. Namun, di balik keunikan ini drama korea memiliki daya tarik yang secara tidak langsung memberikan efek kecanduan bagi penontonnya. Saat mulai melihat drama korea rasa penasaran remaja akan semakin besar untuk melihat kelanjutan cerita daripada drama tersebut. Selain itu beberapa genre yang disajikan menambah keinginan remaja untuk melihat drama korea terus menerus. Begitulah drama korea membuat kecanduan bagi remaja yang menikmatinya.

Jika dilihat dari beberapa informan, infroman mengatakan bahwa drama korea membuat kecanduan. Drama korea memiliki durasi waktu tayang kurang lebih 60 menit bahkan beberapa drama memiliki durasi tayang kurang lebih 90 menit. Drama korea juga biasanya hanya tayang dua kali dalam seminggu dan memiliki episode yang beragam umumnya 12-24 episode, namun ada juga drama korea yang memiliki episode yang panjang kurang lebih 50 episode. Dengan hanya tayang dua kali sepekan membuat penonton terkadang menunggu drama selesai dan melihatnya dalam sekali waktu atau biasa disebut dengan marathon drama.Kebiasaan ini sering dilakukan oleh penonton utamanya remaja,

"Saya sendiri bisa menyia-
nyiakan waktu untuk belajar,

sekali lihat drakor bisa sampai begadang padahal besok masuk pagi saat sekolah, dan mungkin dalam Drakor ada adegan yang untuk usia 20+ yang bisa mempengaruhi otak peserta didik"(Yayuk Lailtul Rohmah)

Dengan merelakan waktu belajar dan istirahat mereka untuk melihat drama korea ini membuktikan bahwa drama Korea berpengaruh dalam pendidikan. Mereka akan kehilangan waktu untuk belajar dan tidak fokus dalam pelajaran karena terus teringat drama yang belum mereka selesaikan dan bagus. Tidak hanya itu sebagian besar informan berpendapat bahwa menonton drama koreaakan membuat mereka malas belajar danakan membuat prestasi mereka menurun. 
"Ketika ada drakor yang bagus akan teringat di kepala"(FellyFitri)

Petikan dari wawancara di atas sudah menjelaskan betapa drama korea akan membuat penontonnya kecanduan.

Saat menemukan drama korea yang sesuai dengan selera remaja tersebut, maka remaja tersebut cenderung tidak fokus dan memikirkan drama tersebut.

"Menonton drama bisa membuat kecanduan, maka tugas kuliah terkadang terlupakan. Terkadang jika terlalu banyak menonton drama (maraton) bisa menjadi kelelahan dan sedikit malas, terkadang menunda belajar"'(Dina Arifah Sari)

Selain itu tugas kuliah yang seharusnya diselesaikan tepat waktu menjadi terganggu, akibatnya timbul rasa malas dan keadaan fisik menjadi kelelahan.

Yang ke empat adalah banyaknya adegan yang seharusnya tidak dintonton oleh remaja. Di Korea Selatan beberapa drama masih menayangkan aksi kekerasan fisik bahkan kekerasan seksual yang seharusnya tidak menjadi konsumsi remaja. Dikhawatirkan remaja mengikuti adegan-adegan kekerasan yang ditampilkan dalam drama.

Dari beberapa dampak negatif yang dirasakan oleh informan akibat dari menonton drama korea dalam pendidikan, tidak jarang juga drama korea memberikan dampak positif yang dapat dirasakan oleh penontonnya. Berdasarkan penelitian yang dilakukan oleh Ramlah, dkk pada tahun 2018 dengan judul,"Dampak Perilaku Kecanduan Tayangan Drama Korea Terhadap Prestasi Belajar Kimia Remaja Usia 17 Hingga 19 Tahun Di Sma NegerilManokwari”,yang menyatakan bahwa dampak korea terhadap pembelajaran kimia berdampak negatif dan positif (Ramlah, 2018: 100).

Drama korea memiliki berbagai macam genre dan dengan beragamnya genre tersebut dapat memberikan dampak positif lainnya, seperti pengetahuan baru, cara mencari teman dan pekerjaan yang diperlihatkan dalam dramaCheese in the Trap dan God of Study, paham bahasa korea, dan memiliki motivasi untuk mendapat nilai bagus. Kebudayaan yang ditampilkan seperti adanya sistem hirearki yaitu menghormati orang yang lebih tua dengan menggunakan bahasa yang sopan dan selalu menghormati orang-orang yang lebih muda.Berikut adalah pendapat informan mengenai dampak positif drama korea terhadap pendidikan.

Yang pertama drama korea dengan genre pendidikan banyak diminati oleh sebagian informan karena banyak terdapat informasi seputar pendidikan di Korea Selatan yang tidak bisa didapatkan di Indonesia. Pendidikan di Korea Selatan memang terkenal dengan keketatannya serta betapa keras peserta didik disana untuk belajar demi mendapatkan nilai yang memuaskan dan dapat masuk ke perguruan tinggi yang diinginkan serta jurusan yang memberikan jaminan kerja dengan prestise yang tinggi dalam masyarakat.

Ada salah satu drama koreayang menunjukkan betapa kuliah itu sangat penting. Sky Castle merupakan drama korea yang menceritakan beberapa keluarga yang mengusahakan agaranak mereka masuk keperguruan tinggi favorit dengan jurusan yang favorit juga. Dengan melihat drama ini dapat terbayang betapa kejamnya persaingan untuk berada dalam puncak paramida teratas dalam sebuah pendidikan.Maka dari itulah genre pendidikan sangat diminati oleh kaum remaja dengan berbagai permasalahan yang ditampilkan di drama tersebut. Gaya belajar juga menjadi salah satu hal yang bisa ditiru/dicontoh oleh remaja, agar bisa mendapatkan hasil yang memuaskan.

Yang kedua adalah melihat drama koreatidak hanya sekedar hiburan semata, namun dengan melihat drama korea penonton dalam konteks ini remaja juga 
dapat mempelajari bahasa korea. Seperti yang telah dipaparkan oleh Tabitha Angelicha pada tahun 2020 dengan judul, "Dampak KegemaranMenonton Tayangan Drama Korea terhadap Perilaku Remaja”,yang mengatakan bahwa remaja suka mengadopsi kosa kata bahasa korea dalam kehidupan sehari- hari. Kata-kata yang sering digunakan yaitu 감사합니다

/고마워(kamsahamnida /gomawo) yang memiliki arti terima kasih (Angelicha, 2020: 158). Bahkan sebagian besar dari mereka lancar berbahasa korea tanpa harus membaca terjemahan untuk mengerti artinya.Tak jarang juga merekadapat membaca huruf Hangul atau huruf korea. Hal ini menjadi menarik dimana penggunaan bahasa inggris kini sedikit demi sedikit menjadi tergeser oleh penggunaan bahasa korea. Secara tidak langsung remaja juga melatih kemampuan linguistic mereka dengan belajar bahasa korea secara otodidak. Dengan itu penguasaan bahasa mereka tidak hanya terpaku pada bahasa internasional yaitu bahasa inggris namun, memiliki kemampuan bahasa yang beragam salah satunya adalah bahasa korea.

Yang ketiga adalah adanya drama korea juga memberikan motivasi bagi mereka untuk mencoba merasakan pendidikan ke Korea Selatan. Saat ini sudah banyak program pertukaran guru dan tenaga pengajar, pertukaran ahli di bidang primary and secondary education, kerjasama antar universitas/sekolah, recognition degrees, human resources development, pemberian beasiswa, joint research, dan penyelenggaraan berbagai kegiatan seminar/konferensi/pameranyang dibuka akibat kerjasama pemerintah Indonesia dan Korea Selatan akan membuat motivasi untuk menuntut ilmu semakin tinggi.

\section{KESIMPULAN}

Dari observasi, pembahasan dan wawancara yang dilakukan di atas didapatkan hasil dari penelitian ini adalah pengaruh drama korea terhadap pendidikan remaja memiliki dampak positif dan negatif. Menurut informan, dampak positif dari kegemaran mereka menonton drama korea adalah memberi motivasi belajar, mendapat pengetahuan baru, mengenal budaya pendidikan Korea Selatan, adanya semangat untuk mengikuti program beasiswa keKorea Selatan, belajar bahasa baru.Sedangkan dampak negatifnya adalah malas belajar, menunda pekerjaan, berkurangnya waktu belajar dan istirahat, tidak fokus dalam belajar, kesehatan berkurang dalam menunjang aktivitas sebagai peserta didik, adanya adegan dewasa dan kekerasan yang dikhawatirkan akan ditiru oleh remaja. Oleh karena adanya berbagai dampak negatif dan positif dari tayangan drama korea tersebut, alangkah bijaknya jika orang tua dan orang dewasa dapat mendampingi remaja dalam melihat tayangan yang ditayangkan di televisi mauupun yang didapatkan dalam internet. Dan sebaiknya berikan tayangan yang mendidik remaja serta damping remaja jika merasa kesulitan.

\section{DAFTAR PUSTAKA}

Angelicha, T. (2020). Dampak Kegemaran Menonton

Tayangan Drama Korea Terhadap Perilaku Remaja. EduPsyCouns: Journal of Education, Psychology and Counseling, 2(1), 154-159. Retrieved from https://ummaspul.ejournal.id/Edupsycouns/article/ view/424.

Dasopang, Muhammad Darwis. 2017. Belajar dan Pembelajaran. 
FITRAH: Jurnal Kajian Ilmuilmu Keislaman Vol. 03 No. 02 (333-352).

Herlina. 2013. Bibliotherapy: Mengatasi Masalah Anak dan Remaja melalui Buku. Bandung: Pustaka Cendekia Utama.

Kedutaan Besar Republik Indonesia untuk Republik Korea. 2020. Profil Negara dan Hubungan Bilateral.diakses pada Mei 10, 2020, from http://kemlu .go.id/seoul/id/pages/hubunga n bilateral/558/etc/menu.

Khairunnisa, Dina. 2019. Budaya K-pop dan Kehidupan Remaja (Studi Kasus Pada Mahasiswa Jurusan Pendidikan IPS Fakultas Ilmu Tarbiyah dan Keguruan Universitas Islam Negeri Syarif Hidayatullah Jakarta). Skripsi. Jakarta. Universitas Islam Negeri Syarif Hidayatullah.

Manab, Abdul. 2015. Penelitian Pendidikan Pendekatan Kualitatif. Sleman: Kalimedia.

Nurgahani, Farida. 2014. Metode Penelitian Kualitatif dalam Penelitian Pendidikan Bahasa: Surakarta.

Nurgyantoro, Burhan. 2004. Sastra Anak: Persoalan Genre. Jurnal Humaniora volume 16 (107122). Yogyakarta: Staf Pengajar Fakultas Bahasa dan Seni, Universitas Negeri Yogyakarta.

Ramlah, dkk. (2018). Dampak Perilaku Kecanduan Tayangan Drama Korea Terhadap Prestasi Belajar Kimia Remaja Usia 17 Hingga 19 Tahun di SMA Negeri 1 Manokwari. Arfak
Chem: Chemistry Education Journal, 99-105.

Rohmanto, B. 2014. Drama. Universitas

Terbuka (2014:1.11).

Sapto Adhi, Irwan. 2020. Ini Durasi Tidur Ideal Berdasarkan Usia. http://amp.kompas.cpm/health/r ead/2020/02/03/193100968/inidurasi-tidur-ideal-berdasarkanusia. (diakses 31 Juli 2020)

Windiani \& R, Farida Nurul. 2016. "Menggunakan Metode Etnografi Dalam Penelitian Sosial". Dimensi vol 9 (2) (8792). 